\section{Human capital, income diversification and bank performance-an empirical study of East African banks}

Income diversification in East African banks

\author{
Peter Nderitu Githaiga
}

Department of Accounting and Finance, Moi University, Eldoret, Kenya

\begin{abstract}
Purpose - The purpose of this paper is to examine whether income diversification moderates the relationship between human capital and bank performance.

Design/methodology/approach - The study uses a sample of 53 banks and panel data for the years 2010 2018. The hypotheses are tested through hierarchical multiple regression and the choice between fixed effect and random effect estimation is based on the results of the Hausman test.

Findings - The study finds that human capital and income diversification significantly influence bank performance; however, the direction of the causality varies. While human capital has a positive effect, income diversification has a negative effect. Additionally, the interaction term has a negative and significant effect on bank performance, inferring that income diversification has an antagonistic effect on the human capital and bank performance relationship. For the control variable, liquidity and asset quality negatively affects bank performance while capitalization has a positive effect.

Research limitations/implications - Human capital was measured as human capital efficiency (HCE), which is a quantitative measure of human capital, hence future studies can use qualitative measures. Also, the study focused on commercial banks in East Africa, future researcher may possibly consider other regions and industries, which would shed more insights.

Practical implications - The results of this paper provide valuable insights. Bank managers can get a better understanding of the impact of human capital on bank performance, and the need to invest more in human capital development. Further, the study cautions bank managers that engaging in non-lending activities might destroy the economic value of human capital and ultimately lower performance. The study also recommends that policymakers should address the obstacles to banks' income diversification, for instance relaxing regulations restricting diversification; this might enable banks to leverage related financial service activities for optimal utilization of human capital and improve banks' profitability.

Originality/value - While a good number of previous studies investigated the direct effect of human capital and income diversification on the performance of banks, this study examines the moderating role of income diversification on the relationship between human capital and performance of banks in East Africa.
\end{abstract}

Keywords East Africa, Human capital, Income diversification, Banks, Performance

Paper type Research paper

\section{Introduction}

Firms depend on both tangible and intangible assets for sustained competitive advantage and long run survival. However, in the present era of information and knowledge-based economies, intangible assets, particularly, intellectual capital (IC) are gradually replacing physical capital as critical factors of production and as drivers of sustained long-term profitability (Drucker, 1993; Clarke and Gholamshahi, 2018). This is true for knowledgeintensive service organizations, particularly banks since they are highly innovative and

(C) Peter Nderitu Githaiga. Published in Asian Journal of Accounting Research. Published by Emerald Publishing Limited. This article is published under the Creative Commons Attribution (CC BY 4.0) licence. Anyone may reproduce, distribute, translate and create derivative works of this article (for both commercial and non-commercial purposes), subject to full attribution to the original publication and authors. The full terms of this licence may be seen at http://creativecommons.org/licences/by/4.0/legalcode
Received 1 July 2020 Revised 20 August 2020 5 October 2020

Accepted 3 November 2020 
AJAR

6,1

maintain minimal physical capital due to prudential requirements. All IC dimensions (human capital, structural capital and customer capital) are valuable to an organization. However, human capital is considered the most important to service industries as it not only impacts the quality of services in the short-term but also influences a wide range of organizational outcomes in the long-term (Aryee et al., 2016; Seleim and Bontis, 2013; Mahoney and Kor, 2015).

Furthermore, some researchers claim that human capital is the primary component of IC because it supports developing and applying the other IC components (Kim et al., 2012; Wang and Chang, 2005; Feraru and Mironescu, 2012). Therefore, human capital is at the heart of successful firms owing to its direct and indirect effect on firm performance. This assertion is supported by the resource-based view (RBV), which attributes superior performance and competitive advantage to a firm's specific stock of valuable, rare, inimitable and nonsubstitutable (Barney, 1991; Prahalad and Hamel, 1990). Accordingly, the difference in performance among firms, within and across industries, can be explained by differences in human capital management strategies, such as recruitment, deployment and training. From a similar standpoint, studies have also linked human capital with the attainment of national goals and wealth of nations, further explaining why countries allocate enormous resources on education and healthcare for socio-economic development (Gennaioli et al., 2012; Stewart, 1997).

The human capital and performance relationship has been examined extensively over time; however, the existing literature shows mixed findings. One strand of studies suggests a direct connection that is either positive or negative (Firer and Williams, 2003; Chowdhury et al., 2019). While the other claims an indirect causality (Bontis et al., 2000; Scafarto et al., 2016; Wang and Chang, 2005). Yet a good number of studies assert there is no relationship (Razafindrambinina and Anggreni, 2017; Soewarno and Tjahjadi, 2020). These findings suggest the existence of contingent factors that moderate the human capital and performance relationship. Whereas the RBV theory attributes competitive advantage to firms' stock of human capital, some scholars assert that firms build competitive advantage and economic rent by leveraging their firm-specific resources, such as human capital, through diversification (Merino et al., 2014; Chang and Wang, 2007; Neffke and Henning, 2013). Penrose (1959) also mentioned that firms diversify across business units and industries to exploit alternative uses latent in idle resources and core competencies. In the same line of research, Tidd and Taurins (1999) concluded that diversification leverages not only existing competencies but also develops new ones.

Thus, based on the empirical literature and human capital theories, there seems to be an essential interconnection between human capital, diversification and performance that is not clear. Accordingly, this study contributes to the literature by assessing whether income diversification moderates the relationship between human capital and bank performance among East African banks. The study is motivated by two factors. First, the declining interest-based income owing to financial liberalization deregulation. Second, as a countermeasure, banks are gradually engaging in non-traditional banking services to compensate for the deterioration of interest revenue. This study will enable researchers, practitioners and policymakers to have a more reliable and direct understanding of income diversification's implication on the human capital and bank performance relationship. Besides, the findings will offer more explanation on how banks can leverage their human capital through non-traditional activities for competitive advantage and improved profitability.

This paper is divided into five sections. The first section is an introduction; the research problem is stated. The second section focuses on the literature review section; the definition and the empirical link between the research constructs, human capital, income diversification and bank performance are discussed, and hypotheses developed. The third section presents 
the methodology; the data, the sample, measurement of variables and the research model. The findings of the study are presented in the fourth section. Finally, section five presents the conclusion, puts forward recommendations for practitioners and policymakers, highlights the study's limitations and suggests possible lines of future research.

\section{Literature review}

Human capital represents the essential asset to service organizations, such as banks and professional firms, since the main output is created and delivered by human resources. The quality of services varies from one employee to another (Namasivayam and Denizci, 2006). Bontis et al. (2000) suggest that human capital represents an organization's knowledge stock held by its employees, while Maditinos et al. (2011) view human capital as the "brainpower of the employee inside the company". In a broader sense, all these definitions suggest that human capital represents learning related concepts such as education, training, work experience, competences, and skills and psychological and social ideas, for instance, ability, attitudes and motivation.

Extant literature shows that human capital plays a critical role in firm innovativeness and customer satisfaction (Bornay-Barrachina et al., 2017; Aryee et al., 2016). While some studies have also linked an organization's investment in human capital to improve firm value and profitability (Hejazi et al., 2016; Li et al., 2014). Therefore, a firm's expenditures on employees should be viewed as an investment rather than costs. Expenses on employees' education and training improve human capital rather than physical or financial capital (Bontis et al., 2000; Scafarto et al., 2016), leading to greater employee efficiency and improved organizational performance. Furthermore, firms with quality human capital are likely to have a competitive edge in the marketplace since a knowledgeable workforce is likely to develop new and innovative products (Delery and Roumpi, 2017). Considering the importance of human capital, organizations invest massive resources on employee programs such as recruitment, training and development to equip its human resources with firm-specific skills and capabilities for competitive advantage and superior performance. Macro-level studies further show that human capital accounts for over three-quarters of the developed nation's wealth, thus depicting it as a necessary ingredient for economic development and sustainable development (Becker, 2009; Pelinescu 2015). In the same line of argument, several studies have also shown that human capital fosters innovations and diffusion of technologies, hence stimulating total factor productivity and economic growth (Akhvlediani and Cieślik, 2019; Männasoo, Hein and Ruubel, 2018).

Contrary to the assertions of the RBV theory that attributes firm's competitive advantage and performance emanates to its stock of human capital, the empirical literature shows mixed findings (Firer and Williams, 2003; Wang and Chang, 2005; Razafindrambinina and Anggreni, 2017; Soewarno and Tjahjadi, 2020). Thus, present studies are now exploring factors that either mediate or moderate the relationship. Similarly, scholars on organizational resource management claim that firms can deploy excess firm-specific resources such as human capital through diversification since they are non-tradeable (Chiambaretto and Wassmer, 2019; Fisch and Schmeisser, 2020; Chung et al., 2019). Similarly, some authors have observed that diversifying firms develop new core competencies and capabilities to improve the current business (Lin et al., 2020a, b). Studies have also revealed that firms prefer to diversify into business and industries that require human capital similar to that of their current business, thereby enabling them to leverage excess managerial capital (Fitjar and Timmermans, 2017; Lee et al., 2018; Neffke and Henning, 2013).

A study by Chen et al. (2018) shows that firms with more significant human capital and whose employees have better ex ante employment mobility have a higher likelihood of being acquired. While Lee et al. (2018) observed that human capital complementarities motivated diversification in East African banks 
AJAR

6,1

98

mergers and acquisitions and led to improved post-merger financial performance. Similarly, Mengistu (2009) found that human capital influenced vertical and horizontal export diversification. By and large, these studies emphasize that knowledge-based resources can be leveraged through diversification for economic rent. Moreover, studies suggest that superior performance stems from matching firm's resources to market opportunities (Carnes et al., 2017; Feng et al., 2017).

Scholars have recommended different typologies of diversification (Ansoff, 1965; Ye et al., 2018); however, in the context of the banking industry, income (revenue), diversification is the most important due to the stringent regulations and supervisory oversight that limits banks' freedom to engage in diversification. Income diversification means increasing the number of revenue streams by engaging in non-core (secondary) activities. Concerning the banking sector, income diversification means engaging in nontraditional banking activities, such as securities trading, property management, venture capital and underwriting, that generate non-interest income. Borrowing from Markowitz's (1952) modern portfolio theory, income diversification is a valuable strategy for managing credit risks and stabilizing income. Similarly, studies have also shown that income diversification is associated with improved bank performance (Duho et al., 2019; Chiorazzo et al., 2008); increased bank efficiency (Nguyen, 2018); greater bank market power (Lin et al., 2020a, b) and lower interest margins (Trinugroho et al., 2018). Moreover, banks are likely to benefit from synergies and economies of scale from shared production in related financial services delivery.

Based on theoretical propositions of the RBV and modern portfolio, the banks' competitive advantage and performance are determined by their stock of human capital and leveraging on income diversification. However, there is far from enough empirical studies investigating the link. Most previous studies focused on the direct effect of human capital on bank performance, ignoring that income diversification may moderate the relationship. Income diversification is likely to moderate the human capital and bank performance relationship in several ways. First, by engaging in non-traditional activities, banks are likely to invest more resources in equipping their workforce with the necessary skills to handle the new business, thus improving the value of human capital and, ultimately, performance. Again, engaging in related financial services presents managers with challenging and exciting opportunities for learning how to handle complex decisions. Second, income diversification generates additional financial resources that can be re-invested in improving the current stock of human capital and innovation and ultimately improving bank performance. Third, with the noticeable decline in lending activities, diversifying into non-lending activities offers banks an opportunity to deploy their excess human capital, implying that income diversifications allow for optimal human capital utilization. Finally, banks also enjoy the synergies and economies that arise from related diversification, such as cross-selling and crosssubsidization. Thus, the study hypothesized as follows.

H1. Human capital has a positive and significant effect on bank performance.

H2. Income diversification has a positive and significant effect on bank performance.

H3. Income diversification significantly moderates the relationship between human capital and bank performance.

\section{Methodology}

3.1 Research design, sample and data

The study was anchored on the positivism paradigm and adopted explanatory and descriptive research designs and was longitudinal. The study employed panel data for the 
period between 2010 and 2018 extracted from the annual reports of registered banking firms within the East Africa region. The population consisted of commercial banks drawn from six countries, which comprise of Uganda (24), Tanzania (41), Rwanda (11), Kenya (42), South Sudan (30) and Burundi (10). The inclusion and exclusion criteria were based on accessibility of data, and the banks had to have to be in operation in the entire period. Also, the banking firm should not have undergone substantial corporate restructuring to ensure the consistency of data. Thus, the final sample consisted of 53 commercial banks, which yielded a total of 477 firm-year observations.

\subsection{Measurement of variables}

The study had a total of six variables: one dependent variable (bank performance), the independent variable (human capital), a moderator (income diversification) and three control variables (bank capitalization, asset quality and liquidity). A brief description of the variables and their measurement is as follows.

3.2.1 Bank performance. Bank performance was measured by the return on assets (ROA) as used in previous studies (Duho et al., 2019; Berger et al., 2010). A higher return on assets shows better utilization of banks' assets to generate profits, while lower ROA indicates inefficient use of assets.

3.2.2 Human capital. The value-added intellectual capital $\left(\mathrm{VAIC}^{\mathrm{TM}}\right)$, devised by Pulic (2000), formed the basis of measuring human capital. The key coefficient of VAIC ${ }^{\mathrm{TM}}$ is value added (VA). VAIC ${ }^{\mathrm{TM}}$ is a composite sum of three indicators. Human capital efficiency (HCE) that measures the efficiency of human capital resources employed. Structural capital efficiency (SCE) is an indicator of structural capital (innovation capital, process capital, and customer capital). Capital employed efficiency (CEE), which shows the value created for every monetary unit invested in financial or physical capital. The VAIC ${ }^{\mathrm{TM}}$ model is formalized as:

$$
\mathrm{VAIC}^{\mathrm{TM}}=\mathrm{HCE}+\mathrm{SCE}+\mathrm{CEE}
$$

where $\mathrm{VAIC}^{\mathrm{TM}}=\mathrm{VA}$ is the intellectual capital coefficient; $\mathrm{HCE}=$ human capital efficiency; $\mathrm{SCE}=$ structural capital efficiency and CEE = capital employed efficiency. The VA is obtained by subtracting operating expenses from total revenue. HCE is calculated by dividing the VA by the total employee costs or payroll expenditure (staff salaries, pension, insurance, and related expenses). SCE is calculated by dividing the total expenses on structural capital by the firm's VA. CEE is obtained by dividing its VA by the book value of the net assets. A high coefficient indicates higher value creation using the firm's resources, including IC.

3.2.3 Income diversification is used as the moderating variable. Banks' income comprises the interest income (generated from lending activities) and non-interest income (earned from non-lending activities). These two revenue streams construct the Herfindahl-Hirschman Index (HHI) of income specialization (Nepali, 2018; Chiorazzo et al., 2008). HHI is computed, as shown below.

$$
\mathrm{HHI}=\left[\left\{\left(\frac{\mathrm{NET}}{\mathrm{NETOP}}\right)^{2}+\left(\frac{\mathrm{NII}}{\mathrm{NETOP}}\right)^{2}\right\}\right]
$$

where NET is the net interest income, NII is the net non-interest income and NETOP denotes net operating income, which equals to net non-interest income (NII) plus net-interest income (NET). As the HHI rises, the bank becomes more concentrated and less diversified, $\mathrm{HHI}$ varies between 0 and 1.0 (Stiroh and Rumble, 2006; Mercieca et al., 2007). Therefore, the study measures income diversification as: diversification in East African banks 
AJAR

6,1

\subsection{Control variables}

The study incorporated several control variables into the estimation model, bank capitalization, asset quality and liquidity.

3.3.1 Bank capitalization. An increase in bank capital reduces the expected costs of financial distress and bankruptcy which results in a lower cost of capital (Frigerio and Vandone, 2018). Besides, lenders consider adequately capitalized banks as capable of dealing with adverse macro-economic factors. Similarly, to pay dividends to shareholders, bank managers are constrained to operate efficiently by minimizing costs to increase profits. Thus, the study hypothesis that well-capitalized banks have a greater capacity and are likely to report higher performance. This study measures bank capitalization as the ratio of equity to total assets (Ekinci and Poyraz, 2019).

3.3.2 Asset quality. Berger and DeYoung (1997) contend that asset quality is a significant predictor of bank insolvency. Thus, bank asset quality reflects bank monitoring since low asset quality is likely to have a negative impact on a bank's risk-adjusted performance. Furthermore, when the asset quality is lower, it may pursue more diversified revenue streams to compensate for the deterioration of the loan quality, hence reducing income volatility (Ahamed, 2017). Asset quality is measured as the ratio of non-performing loans (NPLs) to gross loans and advances (Lin and Zhang, 2009; Ahamed, 2017).

3.3.3 Banks liquidity. Many studies posit a positive relationship between banks' liquidity and their financial performance (Athanasoglou et al., 2008). Nonetheless, there are counterarguments: excess liquidity is accompanied by high storage costs (Staikouras et al., 2008) and lower returns (Kosmidou et al., 2007). Although liquid assets might decrease liquidity risk, they may well carry high costs that negatively affect bank performance. Arguably, banks with higher liquidity perform better than banks with lower levels of liquid assets.

In comparison, banks with lower liquidity would underperform banks with more liquid assets while raising their liquidity levels, a phenomenon referred to as the 'bad luck hypothesis' (Berger and De-Young, 1997). In contrast, liquid assets are generally associated with lower return rates and, consequently, higher liquidity would lead to lower financial performance. Liquidity is measured as the ratio of total loans and advances to total assets, which is an indicator of the percentage of bank assets tied up in loans and other advances (Kosmidou et al., 2007; Bunda and Desquilbet, 2008).

\subsection{Research model}

This study used hierarchical regression analysis to test the three research hypotheses. Considering that the current study's main objective was to analyse the moderating effect of income diversification on the human capital and bank performance relationship, the following set of multiple regression equations were developed:

Model 1: Testing the impact of the control variables on the dependent variable.

$$
\mathrm{BP}=\alpha+\beta_{1} \mathrm{CAP}+\beta_{2} \mathrm{AQ}+\beta_{3} \mathrm{LQ}+\varepsilon
$$

Model 2: Testing the effect of the independent variable on the dependent variable.

$$
\mathrm{BP}=\alpha+\beta_{1} \mathrm{CAP}+\beta_{2} \mathrm{AQ}+\beta_{3} \mathrm{LQ}+\beta_{4} \mathrm{HC}+\varepsilon
$$


Model 3: Testing the effect of the predictor variable and the moderator on the dependent variable.

$$
\mathrm{BP}=\alpha+\beta_{1} \mathrm{CAP}+\beta_{2} \mathrm{AQ}+\beta_{3} \mathrm{LQ}+\beta_{4} \mathrm{HC}+\beta_{5} \mathrm{ID}+\varepsilon
$$

Model 4: Testing for the moderating effect.

$$
\mathrm{BP}=\alpha+\beta_{1} \mathrm{CAP}+\beta_{2} \mathrm{AQ}+\beta_{3} \mathrm{LQ}+\beta_{4} \mathrm{HC}+\beta_{5} \mathrm{ID}+\beta_{6} \mathrm{HC} X \mathrm{ID}+\varepsilon
$$

where $\mathrm{BP}=$ bank performance, $\mathrm{HC}=$ human capital, $\mathrm{ID}=$ income diversification, $\mathrm{CAP}=$ capitalization, $\mathrm{AQ}=$ asset quality, $\mathrm{LQ}=$ liquidity

\section{Results and discussions}

\subsection{Descriptive statistics}

The summary descriptive statistics of the research variables are presented in Table 1. Bank performance (ROA) has a mean of 0.03 , suggesting a low profitability level of commercial banks in East Africa. The high SD of 0.02 indicates that the selected banks have a high variation in their financial performance. The mean score of human capital is 2.87 , suggesting that East African banks create an average of 2.87 monetary units for every one monetary unit invested in human resources. Table 1 further shows that income diversification has a mean score of 0.41 , suggesting that East African banks engage moderately in non-traditional activities. Further, banks' liquidity level is moderate, as shown by the mean score of 0.57 . The average asset quality of 0.09 shows a low level of nonperforming loans. Bank capitalization has a mean score of 0.16 . The lower degree of capitalization implies that the selected banks are assuming higher risks.

\subsection{Correlation analysis}

The correlation and magnitude of the variables are presented in the correlation matrix (see Table 2).

\begin{tabular}{lccccr}
\hline Variable & Obs & Mean & SD & Min & Max \\
\hline Bank performance & 477 & 0.03 & 0.02 & 0.01 & 0.19 \\
Human capital & 477 & 2.87 & 0.82 & 1.73 & 7.45 \\
Income diversification & 477 & 0.41 & 0.07 & 0.21 & 0.50 \\
Liquidity & 477 & 0.57 & 0.12 & 0.04 & 0.85 \\
Asset quality & 477 & 0.09 & 0.09 & 0.00 & 0.51 \\
Capitalization & 477 & 0.16 & 0.04 & 0.06 & 0.29
\end{tabular}

Note(s): SD, standard deviation; Min, minimum value; Max, maximum value

Table 1. Summary statistics

\begin{tabular}{lcccccr}
\hline Variable & BP & HC & ID & LQ & AQ & CAP \\
Bank performance(BP) & 1.000 & & & & & \\
Human capital (HC) & $0.416^{*}$ & 1.000 & & & & \\
Income diversification (ID) & -0.099 & -0.036 & 1.000 & & & \\
Liquidity (LQ) & $-0.091^{*}$ & -0.028 & $-0.212^{*}$ & 1.000 & & \\
Asset quality (AQ) & $-0.414^{*}$ & $-0.239^{*}$ & -0.043 & 0.085 & 1.000 & Table 2. \\
Capitalization (CAP) & $0.126^{*}$ & 0.089 & -0.010 & -0.059 & $0.102^{*}$ & Pearson correlation \\
Note(s): *Significant at 5\% & & & & & & matrix \\
\hline
\end{tabular}


AJAR

6,1

102
Table 3.

Results of regression models (1), (2), (3) and (4)
Pearson's correlation test is applied to test the relationship between the research variables. The findings in Table 2 indicate that human capital $(r=0.416 ; \rho<0: 01)$ and capitalization $(r=0.126 ; \rho<0: 01)$ are significantly and positively correlated with bank performance. While liquidity $(r=-0.091 ; \rho<0: 01)$ and asset quality $(r=0.414 ; \rho<0: 01)$ are significantly and negatively correlated with bank performance. However, income diversification is the only explanatory variables that is negatively and not significantly correlated with bank performance $(r=-0.099 ; \rho>0.05)$.

\subsection{Multiple regression analysis}

The study employed hierarchical multiple linear regression analysis to determine the moderating effect of income diversification on the relationship between banking firms' human capital performance in East Africa. The results of the hypotheses test are shown in Table 3 as follows.

In column 1, the regression results of bank performance and the control variables (model 1) are reported. Based on the results, capitalization had a positive and significant effect on bank performance, and the findings are consistent with those of previous studies (Ekinci and Poyraz, 2019; Belkhaoui et al., 2014; Frigerio and Vandone, 2018). Therefore, this study argues that well-capitalized banks are more profitable since they are less reliant on external funding, inferring the advantage of a lower capital cost.

The study found that asset quality had a negative and significant effect on bank performance regarding asset quality. The results were supported by previous studies (Alharbi, 2017; Salike and Ao, 2018). A possible explanation of these findings is the existence of weak credit management practices (borrowers screening, monitoring and collection policies) and macro-economic factors that deteriorate the quality of loan portfolio, hence exposing banks to higher credit risks. Thus, banks with high NPLs are less profitable and are likely to suffer from financial distress, due to the increased level of nonperforming loan provisions.

Liquidity had a negative and statistically insignificant effect on bank performance. The association suggests that highly liquid banks are less profitable. Although a high ratio of the loan-to-assets ratio is an indicator of the availability of sufficient assets that can be converted into cash, holding too much idle money indicates low efficiency in assets utilization. Banks are likely to lose the opportunity cost of earning profit through lending, ultimately leading to low profitability. Therefore, the results confirm that high liquidity can be undesirable as a low one, and managers must maintain an optimal liquidity level.

\begin{tabular}{lcccc}
\hline $\begin{array}{l}\text { Dependent variable } \\
\text { Bank performance(ROA) }\end{array}$ & Model & Model & Model & Model \\
& 1 & 2 & 3 & 4 \\
\hline Asset quality & $-0.075^{* *}(-6.63)$ & $-0.066^{* *}(-6.98)$ & $-0.067^{* *}(-7.09)$ & $-0.064^{* *}(-6.60)$ \\
Capitalization & $0.072^{* *}(2.82)$ & $0.055^{* *}(2.50)$ & $0.056^{* *}(2.56)$ & $0.053^{* *}(2.30)$ \\
Liquidity & $-0.009(-1.13)$ & $-0.009(-1.26)$ & $-0.012(-1.65)$ & $-0.013(-1.73)$ \\
Human capital & & $0.009^{* *}(7.11)$ & $0.009^{* *}(7.17)$ & $0.030^{* *}(5.02)$ \\
Income diversification & & & $-0.022^{* *}(-1.98)$ & $0.118^{* *}(2.78)$ \\
Human capita**income & & & & $-0.052^{* *}(-3.51)$ \\
diversification & 0.029 & 0.003 & 0.014 & -0.041 \\
cons & 0.0635 & 0.514 & 0.537 & 0.001 \\
Hausman (Pr $>$ chi $\left.{ }^{2}\right)$ & 0.201 & 0.292 & 0.289 & 0.240 \\
$R$-squared & 477 & 477 & 477 & 477 \\
No of observations & & &
\end{tabular}


Column 2 presents the results of model 2 that sought to examine the effect of human capital on bank performance. Based on the findings, human capital had a positive and significant impact on bank performance; therefore, hypothesis $\mathrm{H} 1$ is supported. The results are also consistent with previous studies (Li et al., 2014; Kor and Leblebici, 2005; Maditinos et al., 2011) and the RBV theory. Therefore, efficient utilization of human capital will positively impact bank performance, which further stresses the importance of knowledge-based resources to a firm's competitive advantage, particularly service organizations like banks. However, the low beta coefficient $(\beta=0.009)$ provides additional empirical evidence that human capital has not yet been optimally used by banks in East Africa to generate profits. Although banks are highly innovative, the findings demonstrate that banks are more dependent on physical capital than knowledge-based assets such as human capital. These results emphasize the importance of knowledge resources as a source of competitive advantage and, ultimately, firm performance. Therefore, an organization's investment in human resources has a favourable impact on performance.

In contrast to H1, the results of model 3 presented in column 3 shows that income diversification had a negative and significant effect on the bank performance $\beta=-0.022$; $\rho<0.05$ ); thus, $\mathrm{H} 2$ is not supported. The finding is supported by previous studies (Stiroh and Rumble, 2006; Berger et al., 2010).) and contrary to modern portfolio theory. The negative relationship between income diversification and bank performance provides further evidence on the dark side of diversification, which can be attributed to several factors; first, lack of managerial expertise in managing non-traditional banking activities. Second, gain from revenue diversification gains could be eroded quickly by the costs associated with nontraditional activities. Third, bank managers might easily fall prey to the newness trap, thus neglecting mainstream banking activities. Hence, bank managers should focus on a strategy that focuses on increasing their interest income to avoid potential losses from diversifying into non-lending activities.

Column 3 presents the results of model 4, which was used to test the hypothesis H3; whether income diversification moderated the relationship between human capital and bank performance. The findings show that the interaction term of human capital and income diversification had a negative and significant effect on bank performance $(\beta=-0.052$; $\rho<0.05)$. Further, after the interaction's inclusion, the results revealed that the model's overall explanatory power ( $R$-squared) reduced from 0.292 in model 3 to 0.240 in model 4 . As a result, the hypothesis H3 is rejected. Several factors can explain the negative and significant moderating effect of income diversification on the human capital and bank performance. First, though firms prefer diversifying into related businesses or industries where they can take advantage of skills sharing, skill sharing can only translate into a competitive advantage if the operational skills are compatible and transferable, leading to a synergetic benefit across the firm. Thus, this study's findings suggest that bank managers and employees might lack the requisite specialized skills and experience to carry out non-lending activities, which lowers labour productivity. Second, internal information asymmetries increase with the degree of diversification. According to the bounded rationality theory, internal information asymmetry limits workers' ability to synthesize heterogeneous information from the diverse business lines, which ultimately lowers their efficiency. Also, increased business activities lead to information overload, hence disallowing employees from taking advantage of learning opportunities that may arise from income diversification. Finally, bank managers may allocate too much of their managerial capital to integrate non-lending activities with lending activities, leading to an inefficient allocation of human capital.

\section{Conclusion}

The importance of knowledge-based capital is gradually increasing, particularly in today's era of knowledge and information-based economies. Specifically, intangible assets are critical diversification in East African banks 
AJAR

6,1

104

to the highly innovative banking sector. Again, financial liberalization and deregulation have changed the traditional banking business leading to stiff competition and decline in interest income prompting banks to diversify into non-traditional activities to compensate for the lost revenue. From this background, this study sought to examine whether income diversification moderated the relationship between East African banks' human capital and performance. To test the study's hypotheses, the study used hierarchical multiple regression; and the choice between the fixed effect regression and the random effect estimation was based on the Hausman test. The findings revealed that human capital had a positive and significant impact on bank performance, emphasizing the importance of knowledge-based capital to service organizations.

On the other hand, income diversification had a significant adverse effect on bank performance. Therefore, the study concludes that focused banks are more profitable than diversified ones. Finally, the study found that income diversification had a negative and significant moderating effect on the relationship between human capital and bank performance. Hence, leveraging IC through non-traditional banking activities lowers the impact of human capital on bank performance.

\subsection{Practical implication}

On the practical side, managers must pay closer attention to human capital and its positive impact on firm performance. Similarly, managers must be conscious of the latent potential for leveraging their human capital through non-traditional activities without compromising the mainstream activities. In particular, to preserve the value of the accumulated human capital investments and enhance financial performance, banks should diversify into related industries or businesses to avoid destroying their human capital.

Policymakers need to pay attention to regulatory impediments and agency problems that might prevent banks from attaining an optimal income diversification level. The study also noted that human capital had a low impact on bank performance, which calls for governments and banks to make additional investments in human capital development.

\subsection{Limitations of the study}

Despite the novelty of the finding, there are several limitations which can be addressed in future research. This study measures human capital as HCE, as guided by Pulic's VIAC ${ }^{\mathrm{TM}}$, which does not allow the use of qualitative measures of human capital such as education and training. Thus, future studies can consider qualitative indicators of human capital. Second, the study focused on commercial banks in East Africa; therefore, future studies focussing on other regions and industries would shed more insights.

\section{References}

Ahamed, M.M. (2017), “Asset quality, non-interest income, and bank profitability: evidence from Indian banks”, Economic Modelling, Vol. 63, pp. 1-14.

Akhvlediani, T. and Cieślik, A. (2019), "Human capital, technological progress and technology diffusion across Europe: education matters”, Empirica, Vol. 47, pp. 475-493, pp. 1-19.

Alharbi, A.T. (2017), "Determinants of Islamic banks' profitability: international evidence", International Journal of Islamic and Middle Eastern Finance and Management, Vol. 10 No. 3, pp. 331-350.

Ansoff, H.I. (1965), Corporate Strategy: An Analytic Approach to Business Policy for Growth and Expansion, McGraw-Hill Companies.

Aryee, S., Walumbwa, F.O., Seidu, E.Y. and Otaye, L.E. (2016), "Developing and leveraging human capital resource to promote service quality: Testing a theory of performance", Journal of Management, Vol. 42 No. 2, pp. 480-499. 
Athanasoglou, P., Brissimis, S. and Delis, M. (2008), "Bank specific, industry-specific and macroeconomic determinants of bank profitability", Journal of International Financial Markets, Institutions and Money, Vol. 18, pp. 121-136.

Barney, J. (1991), "Firm resources and sustained competitive advantage", Journal of Management, Vol. 17 No. 1, pp. 99-120.

Income diversification in East African banks

Becker, G.S. (2009), Human Capital: A Theoretical and Empirical Analysis with Special Reference to Education, University of Chicago Press, Chicago, IL.

Belkhaoui, S., Lakhal, L., Lakhal, F. and Hellara, S. (2014), "Market structure, strategic choices and bank performance: a path model”, Managerial Finance, Vol. 40 No. 6, pp. 538-564.

Berger, A. and DeYoung, R. (1997), "Problem loans and cost efficiency in commercial banks", Journal of Banking and Finance, Vol. 21 No. 6, pp. 849-870.

Berger, A.N., Hasan, I. and Zhou, M. (2010), "The effects of focus versus diversification on bank performance: evidence from Chinese banks", Journal of Banking and Finance, Vol. 34 No. 7, pp. 1417-1435.

Bontis, N., Keow, W.C.C. and Richardson, S. (2000), "Intellectual capital and business performance in Malaysian industries", Journal of Intellectual Capital, Vol. 1 No. 1, pp. 85-100.

Bornay-Barrachina, M., López-Cabrales, A. and Valle-Cabrera, R. (2017), "How do employment relationships enhance firm innovation? The role of human and social capital", The International Journal of Human Resource Management, Vol. 28 No. 9, pp. 1363-1391.

Bunda, I. and Desquilbet, J.B. (2008), "The bank liquidity smile across exchange rate regimes", International Economic Journal, Vol. 22 No. 3, pp. 361-386.

Carnes, C.M., Chirico, F., Hitt, M.A., Huh, D.W. and Pisano, V. (2017), "Resource orchestration for innovation: structuring and bundling resources in growth-and maturity-stage firms", Long Range Planning, Vol. 50 No. 4, pp. 472-486.

Chang, S.C. and Wang, C.F. (2007), "The effect of product diversification strategies on the relationship between international diversification and firm performance", Journal of World Business, Vol. 42 No. 1, pp. 61-79.

Chen, D., Gao, H. and Ma, Y. (2018), "Human capital driven acquisition: evidence from the inevitable disclosure doctrine", Working paper, Fudan University, and University of International Business and Economics, SSRN 2713600, doi: 10.2139/ssrn.2713600.

Chiambaretto, P. and Wassmer, U. (2019), "Resource utilization as an internal driver of alliance portfolio evolution: the Qatar Airways case (1993-2010)", Long Range Planning, Vol. 52 No. 1, pp. 51-7.

Chiorazzo, V., Milani, C. and Salvini, F. (2008), "Income diversification and bank performance: evidence from Italian banks", Journal of Financial Services Research, Vol. 33 No. 3, pp. 181-203.

Chowdhury, L., Rana, T. and Azim, M. (2019), "Intellectual capital efficiency and organisational performance: in the context of the pharmaceutical industry in Bangladesh", Journal of Intellectual Capital, Vol. 20 No. 6, pp. 784-806.

Chung, D., Kim, M.J. and Kang, J. (2019), "Influence of alliance portfolio diversity on innovation performance: the role of internal capabilities of value creation", Review of Managerial Science, Vol. 13 No. 5, pp. 1093-1120.

Clarke, T. and Gholamshahi, S. (2018), "Developing human capital for knowledge based economies", Innovation in the Asia Pacific, Springer, Singapore, pp. 247-270.

Delery, J.E. and Roumpi, D. (2017), "Strategic human resource management, human capital and competitive advantage: is the field going in circles?", Human Resource Management Journal, Vol. 27 No. 1, pp. 1-21.

Drucker, P. (1993), Post-capitalist Society, Harper Business, New York. NY.

Duho, K.C.T., Onumah, J.M. and Owodo, R.A. (2019), "Bank diversification and performance in an emerging market”, International Journal of Managerial Finance, Vol. 16 No. 1, pp. 120-138. 
AJAR

6,1

106

Ekinci, R. and Poyraz, G. (2019), "The effect of credit risk on financial performance of deposit banks in Turkey”, Procedia Computer Science, Vol. 158, pp. 979-987.

Feng, H., Morgan, N.A. and Rego, L.L. (2017), "Firm capabilities and growth: the moderating role of market conditions", Journal of the Academy of Marketing Science, Vol. 45 No. 1, pp. 76-92.

Feraru, A. and Mironescu, R. (2012), "The intellectual capital and the learning organization”, Journal of International Scientific Publication, Vol. 6 No. 3, pp. 30-40.

Firer, S. and Williams, S.M. (2003), "Intellectual capital and traditional measures of corporate performance", Journal of Intellectual Capital, Vol. 4 No. 3, pp. 348-360.

Fisch, J.H. and Schmeisser, B. (2020), "Phasing the operation mode of foreign subsidiaries: reaping the benefits of multinationality through internal capital markets", Journal of International Business Studies, pp. 1223-1255.

Fitjar, R.D. and Timmermans, B. (2017), "Regional skill relatedness: towards a new measure of regional related diversification”, European Planning Studies, Vol. 25 No. 3, pp. 516-538.

Frigerio, M. and Vandone, D. (2018), "Bank ownership and firm-level performance: an empirical assessment of state-owned development banks", Contemporary Issues in Banking, Palgrave Macmillan, Cham, pp. 197-219.

Gennaioli, N., La Porta, R., Lopez-de-Silanes, F. and Shleifer, A. (2012), "Human capital and regional development”, The Quarterly Journal of Economics, Vol. 128 No. 1, pp. 105-164.

Hejazi, R., Ghanbari, M. and Alipour, M. (2016), "Intellectual, human and structural capital effects on firm performance as measured by Tobin's Q", Knowledge and Process Management, Vol. 23 No. 4, pp. 259-273.

Kim, T., Kim, W.G., Park, S.S.S., Lee, G. and Jee, B. (2012), "Intellectual capital and business performance: what structural relationships do they have in upper-upscale hotels?”, International Journal of Tourism Research, Vol. 14 No. 4, pp. 391-408.

Kor, Y.Y. and Leblebici, H. (2005), "How do interdependencies among human-capital deployment, development, and diversification strategies affect firms' financial performance?", Strategic Management Journal, Vol. 26 No. 10, pp. 967-985.

Kosmidou, K., Pasiouras, F. and Tsaklanganos, A. (2007), "Domestic and multinational determinants of foreign bank profits: the case of Greek banks operating abroad", Journal of Multinational Financial Management, Vol. 17 No. 1, pp. 1-15.

Lee, K.H., Mauer, D.C. and Xu, E.Q. (2018), "Human capital relatedness and mergers and acquisitions", Journal of Financial Economics, Vol. 129 No. 1, pp. 111-135.

Li, Q., Qian, X., Gong, S. and Tao, Z. (2014), "Impact of human capital investment on firm performance: an empirical study of Chinese industrial firms", Proceedings of the Eighth International Conference on Management Science and Engineering Management, Springer, Berlin, Heidelberg, pp. 1269-1280.

Lin, X. and Zhang, Y. (2009), "Bank ownership reform and bank performance in China", Journal of Banking and Finance, Vol. 33 No. 1, pp. 20-29.

Lin, H.E., Hsu, I.C., Hsu, A.W. and Chung, H.M. (2020a), "Creating competitive advantages: interactions between ambidextrous diversification strategy and contextual factors from a dynamic capability perspective”, Technological Forecasting and Social Change, Vol. 154, p. 119952.

Lin, Y., Shi, X. and Zheng, Z. (2020b), "Diversification strategy and bank market power: does foreign ownership matter?", Applied Economics Letters, pp. 1-5.

Männasoo, K., Hein, H. and Ruubel, R. (2018), "The contributions of human capital, R\&D spending and convergence to total factor productivity growth”, Regional Studies, Vol. 52 No. 12, pp. 1598-1611.

Maditinos, D., Chatzoudes, D., Tsairidis, C. and Theriou, G. (2011), "The impact of intellectual capital on firms' market value and financial performance", Journal of Intellectual Capital, Vol. 12 No. 1, pp. 132-151. 
Mahoney, J.T. and Kor, Y.Y. (2015), "Advancing the human capital perspective on value creation by joining capabilities and governance approaches", Academy of Management Perspectives, Vol. 29 No. 3, pp. 296-308.

Markowitz, H. (1952), "Portfolio selection”, The Journal of Finance, Vol. 7 No. 1, pp. 77-91.

Mengistu, A.A. (2009), "Do physical and human capital matter for export diversification?: a comparative analysis of sub-saharan Africa and East asia", African and Asian Studies, Vol. 8 Nos 1-2, pp. 1-46, doi: 10.1163/156921009X413144.

Mercieca, S., Schaeck, K. and Wolfe, S. (2007), "Small European banks: benefits from diversification?”, Journal of Banking and Finance, Vol. 31 No. 7, pp. 1975-1998.

Merino, P.B., Grandval, S., Upson, J. and Vergnaud, S. (2014), "Organizational slack and the capability life-cycle: the case of related diversification in a technological SME", The International Journal of Entrepreneurship and Innovation, Vol. 15 No. 4, pp. 239-250.

Namasivayam, K. and Denizci, B. (2006), "Human capital in service organizations: identifying value drivers", Journal of Intellectual Capital, Vol. 7 No. 3, pp. 381-393.

Neffke, F. and Henning, M. (2013), "Skill relatedness and firm diversification", Strategic Management Journal, Vol. 34 No. 3, pp. 297-316.

Nepali, S.R. (2018), "Income diversification and bank risk-return trade-off on the Nepalese commercial banks", Asian Economic and Financial Review, Vol. 8 No. 2, pp. 279-293.

Nguyen, T.L.A. (2018), "Diversification and bank efficiency in six ASEAN countries", Global Finance Journal, Vol. 37, pp. 57-78.

Pelinescu, E. (2015), “The impact of human capital on economic growth”, Procedia Economics and Finance, Vol. 22 No. 1, pp. 184-190.

Penrose, E.T. (1959), The Theory of the Growth of the Firm, Oxford University Press, New York, NY.

Prahalad, C.K. and Hamel, G. (1990), The core competence of the corporation, Harvard Business Review, May-June, pp. 79-91.

Pulic, A. (2000), "VAIC ${ }^{\mathrm{TM}}$ : an accounting tool for IC management", International Journal of Technology Management, Vol. 20 Nos 5-8, pp. 702-714.

Razafindrambinina, D. and Anggreni, T. (2017), "Intellectual capital and corporate financial performance of selected listed companies in Indonesia", Malaysian Journal of Economic Studies, Vol. 48 No. 1, pp. 61-77.

Salike, N. and Ao, B. (2018), "Determinants of bank's profitability: role of poor asset quality in Asia", China Finance Review International, Vol. 8 No. 2, pp. 216-231.

Scafarto, V., Ricci, F. and Scafarto, F. (2016), "Intellectual capital and firm performance in the global agribusiness industry", Journal of Intellectual Capital, Vol. 17 No. 3, pp. 530-552.

Seleim, A. and Bontis, N. (2013), "National intellectual capital and economic performance: empirical evidence from developing countries", Knowledge and Process Management, Vol. 20 No. 3, pp. 131-140.

Soewarno, N. and Tjahjadi, B. (2020), "Measures that matter: an empirical investigation of intellectual capital and financial performance of banking firms in Indonesia”, Journal of Intellectual Capital.

Staikouras, C., Mamatzakis, E. and Koutsomanoli-Filippaki, A. (2008), "Cost efficiency of the banking industry in the South Eastern European region", Journal of International Financial Markets, Institutions and Money, Vol. 18 No. 5, pp. 483-497.

Stewart, T. (1997), Intellectual Capital: The New Wealth of Organizations, Doubleday/Currency, New York, NY.

Stiroh, K.J. and Rumble, A. (2006), "The dark side of diversification: the case of US financial holding companies", Journal of Banking and Finance, Vol. 30 No. 8, pp. 2131-2161. 
AJAR

6,1

Tidd, J. and Taurins, S. (1999), "Learn or leverage? Strategic diversification and organizational learning through corporate ventures", Creativity and Innovation Management, Vol. 8 No. 2, pp. 122-129.

Trinugroho, I., Risfandy, T. and Ariefianto, M.D. (2018), "Competition, diversification, and bank margins: evidence from Indonesian Islamic rural banks”, Borsa Istanbul Review, Vol. 18 No. 4, pp. 349-358.

Wang, W.Y. and Chang, C. (2005), "Intellectual capital and performance in causal models", Journal of Intellectual Capital, Vol. 6 No. 2, pp. 222-236.

Ye, M., Lu, W., Flanagan, R. and Ye, K. (2018), "Diversification in the international construction business", Construction Management and Economics, Vol. 36 No. 6, pp. 348-361.

\section{Further reading}

Ansoff, H.I. (1957), "Strategies for diversification”, Harvard Business Review, Vol. 35 No. 5, pp. 113-124.

Bausch, A. and Pils, F. (2009), "Product diversification strategy and financial performance: metaanalytic evidence on causality and construct multidimensionality", Review of Managerial Science, Vol. 3 No. 3, pp. 157-190.

Chen, C.J. and Huang, J.W. (2009), "Strategic human resource practices and innovation performancethe mediating role of knowledge management capacity", Journal of Business Research, Vol. 62 No. 1, pp. 104-114.

Chen, Y.S., James Lin, M.J. and Chang, C.H. (2006), "The influence of intellectual capital on new product development performance-the manufacturing companies of Taiwan as an example", Total Quality Management and Business Excellence, Vol. 17 No. 10, pp. 1323-1339.

Hitt, M.A., Bierman, L., Shimizu, K. and Kochhar, R. (2001), "Direct and moderating effects of human capital on strategy and performance in professional service firms: a resource-based perspective", Academy of Management Journal, Vol. 44 No. 1, pp. 13-28.

Palacios-Huerta, I. (2001), "The human capital of stockholders and the international diversification puzzle", Journal of International Economics, Vol. 54 No. 2, pp. 309-331.

Sakhartov, A.V. (2017), "Economies of scope, resource relatedness, and the dynamics of corporate diversification”, Strategic Management Journal, Vol. 38 No. 11, pp. 2168-2188.

Sharma, S. and Anand, A. (2019), "Geographical diversification and bank performance: evidence from Indian banks", International Journal of Productivity and Performance Management.

Sherer, P.D. (1995), "Leveraging human assets in law firms: human capital structures and organizational capabilities”, ILR Review, Vol. 48 No. 4, pp. 671-691.

Tihanyi, L., Ellstrand, A.E., Daily, C.M. and Dalton, D.R. (2000), "Composition of the top management team and firm international diversification", Journal of Management, Vol. 26 No. 6, pp. 1157-1177.

\section{Corresponding author}

Peter Nderitu Githaiga can be contacted at: kgithaiga@gmail.com

For instructions on how to order reprints of this article, please visit our website:

www.emeraldgrouppublishing.com/licensing/reprints.htm

Or contact us for further details: permissions@emeraldinsight.com 